\title{
Impact of Organization Learning Capability on Performance Innovation: Mediating role of Information Technology
}

The Journal of Educational Paradigms

2021, Vol. 03(01) 146-150

(c) Authors

ISSN (Print): 2709-202X

ISSN (Online): 2709-2038

DOI: $10.47609 / 0301012021$

\author{
Shamim Akhtar ${ }^{1}$ Dr. Tian Hongyun ${ }^{2}$, Shuja Iqbal ${ }^{3}$, Sheikh Farhan Ashraf ${ }^{4}$, Iram Bashir ${ }^{5}$
}

\begin{abstract}
Modern business innovation has close contact with the adoption of information technology and learning abilities in business procedures. Therefore, this study analysed the impact of organizational learning capability on the innovation performance of the firm. This study also observes the mediating role of information technology adoption between the relationship of organizational learning capability and innovation performance. Data were collected from employees of banks via questionnaire method and furthered analysed by using SmartPLS software. The results explained that organizational learning capability has a positive and significant impact on innovation performance directly. Moreover, the said variables also positively and significantly affect innovation performance when mediated by the firm's information technology adoption.
\end{abstract}

Keywords: Technology Adoption, Innovation Performance, learning capability, organization learning, IT adoption, adopting IT.

Organizations focus on improving the performance innovation, considering it a widely accepted concept to provide value for the customers and profit for the organizations. Moreover, firms also prefer to adopt information technology during innovation to boost creativity, competitive edge, and ultimately the revenue. Information technology (IT) enables firms to manage the opportunities, innovation process, and analyses the innovation performance (Ammirato, Sofo, Felicetti, \& Raso, 2018). This situation is observed both in the manufacturing and services industries. Banks explicitly focus on organizational learning capability and information technology adoption in the financial sector to improve business performance.

Firms mostly try to organize entire management resources, learning abilities, and IT systems to compete with the business environment changes, which untimely aims to attain performance innovation. Organizational learning capability gives stress on the significance of the firm and employees' learning at the workplace. Research explains that "organizations should facilitate all individuals' learning at the workplace and the transfer of intangible resources among individuals and toward the organization. The capacity to learn a key factor if an organization wants to innovate and grow helps improve organizational learning capability. That affects innovation performance since product innovation can be considered an organizational learning process" (PalaciosMarques, Devece-Cara' nana, \& Llopis-Albert, 2016). The capability level of the firm to learn about the advancement of activities performed at the workplace decides what activities can turn into IT systems for innovation of products and services. Therefore, the learning procedure can support the utilization of several innovation schemes in the organization and the whole industry (Rana, Weerakkody, Dwivedi, \& Piercy, 2014).

Business performance and IT adoption also demand the organization's learning capability through which employees learn and perform well for innovation. The business-level becomes an essential consideration while observing organizational learning capability to adopt IT. The central point behind this notion notices how quickly organizations learn and innovate their performance. The research explained that the firm's size presents a significant challenge when it pursues innovation during the process of implementing organizational learning and technology adoption (Hameed, Counsell, \& Swift, 2012).

The effects of e-business adoption in communications on specific aspects of performance are critical. Online communication can enhance efficiency in many ways. For instance, during the field interviews, managers frequently claimed that electronic communications reduced the time to reach customers and speeded up responses to customer inquiries. The managers also indicated that e-business processes helped reduce the cost of material and personnel involved in paper-based communications both within and outside the business unit (Wu, Mahajan, \& Balasubramanian, 2003). According to Ernst and Young (2016), the banking industry generally (all over the world) has invested heavily in the digital environment, and this subsequently leads to alteration of their operations side (Ernst, \& Young, 2016).

\section{Contribution of the study}

This study contributes theoretically in the literature by elaborating on the significance of performance innovation by analyzing the impact of organizational learning capability and information technology (IT) adoption on performance innovation. Direct relations of the organizational learning capability and performance innovation are discussed widely. In contrast, few studies focused on the mediated role of information technology adoption between the organizational learning capability and performance innovation. Therefore statistically, this study contributes the results in a mediation perspective to strengthen the previous literature.

\footnotetext{
${ }^{124}$ School of Management, Jiangsu University, Zhenjiang China. Corresponding author Email: shamimakhtar92@hotmail.com

${ }^{3}$ Lahore School of Business, University of Lahore.

${ }^{5}$ Government College University Faisalabad, Pakistan
} 


\section{Literature Review and Hypotheses Development}

The increasing financial, competitive environment, locally or globally, has led small and large banks to engage in search of new delivery channels through which they can differentiate their products and services and thus achieve competitive advantage (Jenkins, 2007). Adoption of the internet technology changed the methods of outdated business. It helped to move the banks' tasks towards the digital banking systems, providing noticeable development and advancement in the services of the banking business (Alwan \& Al-Zu'bi, 2016). Therefore, the Internet environment assists banks in adopting technology through organizational learning capability through which performance innovation can be achieved. The financial industry is implementing automatic facilities providers, including "ATM (Automated Teller Machine), websites, mobile banking, and money transfers." Websites developed by banks should be very convenient so that the customers can easily understand the knowledge provided about the products and services available in that bank. Studies examined the effects of the adoption of IT in banking activities on performance innovation and the advancement of banks to improve the bank's management. Organizational learning capability and the adaption of IT assist the expansion of internet banking in Pakistan (Raza, Naveed, \& Ali, 2017). Usually, banks need to be encouraged to adopt information technology if they think IT increases the performance innovation and financial improvement (Siddik, Sun, Kabiraj, Shanmugan, \& Yanjuan, 2016).

\section{Organization Learning Capability}

Organizational learning provides a process through which a firm learns to complete the tasks effectively. Learning exists when somewhat transform in the organizational activities, meant to sustain or increase performance. The organizational learning procedure comprises the acquisition, distribution, and utilization of information, thus closely related to innovation performance (Alegre \& Chiva, 2008).

Organizational learning discusses "the capabilities of the workers in a firm, engaging the operational process of acquiring, distributing, explaining, and transforming information into knowledge practices and innovation adoption. Organizational learning also explains the capacity (or processes) within an organization to maintain or improve performance. Based on experience involving "knowledge acquisition (the development or creation of skills, insights, relationships), knowledge sharing (the dissemination to others of what has been acquired by some). The knowledge utilization (integration of the learning so that it is assimilated, broadly available, and can also be generalized to new situations); that enhances the organizational performance and innovation" (Spicer \& Sadler-Smith, 2006).

The technological adoption and innovation performance practices currently represent one of the essential elements of organizational innovative practices and capabilities (Coccia, 2017), which supports the business's effectiveness during challenging periods in the industry. The firm's organizational learning capability remains essential to determine success while using information technology adoption to improve innovation performance (Mandinach \& Cline, 2013). Organizational learning measures the significance of "intangible resource," providing the firm a unique advantage that other firms cannot copy and imitate easily.

$\mathbf{H}_{1}$ : Organization learning capability has a positive and significant impact on performance innovation.

$\mathbf{H}_{2}$ : Organization learning capability has a positive and significant impact on Technology adoption of the firm.

\section{Technology Adoption}

Literature familiarises that information technology, including "introduction of information systems supporting operational processes," discusses the significant influence on the firm (Valiris \& Glykas, 1999). Similarly, "IT smart objects (SOs), cloud computing, big data, and artificial intelligence" continue influencing innovation performance (Monostori, 2014). Technological innovation practice has been considered the essence of innovative practices to enhance organizational outcome and performance, especially for the manufacturing industries (Yam, Lo, Tang, \& Lau, 2011).

Nowadays, many banks observed the vital prominence of technology adoption and decided to incorporate information technology in numerous dimensions of banking services. Institute of technologies re-counted that "in the financial industry, banking products and services such as internet banking, mobile banking, online services, websites and another type of cashless system, expected to surplus over US\$10tn over the next decade" (The Demand Institute, 2017).

Technology adoption by the firms needs to increase the network of technology users (customers). The cost and benefits strategy can be used effectively due to the high amount of interrelation amongst technologies. Network effect influences the business positively "when the technology's value to a user increases with the number of total users in the network. Studies on the telecommunications industry have found similar evidence. In 1998 researchers looked at the adoption of electronic switching, giving a firm better advantage of performance innovation through technology adoption" (Hall \& Khan, 2003).

H3: Technology adoption has a positive and significant impact on performance innovation.

$\mathbf{H}_{4}$ : Organization learning capability has a positive and significant impact on performance innovation when mediated by the firm's technology adoption.

\section{Innovation Performance}

Innovation performance describes the "successful implementation of creative ideas within an organization" therefore, the concept is closely associated with the workforce's organizational learning capacity. Innovation performance helps the firms successfully introduce new products and services, providing vital lifeblood to the organizations (Alegre \& Chiva, 2008). Organization from time to time need the advancement of activities for attaining competitive advantage. Along with learning capability, the adoption of information technology significantly influences innovation performance through which organizations become competent and efficient (Laput, Zhang, \& Harrison, 2017). Activities performed using information technology help the firms achieve the best total benefits (Ammirato, Sofo, Felicetti, \& Raso, 2018). Because fast and up to date, innovation has become a critical feature for improving innovation performance and survival 
and attaining benefits from a competitive advantage in the industry (Bueno \& Ordonez, 2004).

Past research revealed that "from the organizational context, the need for innovation, up-to-date, convenient and usage of reliable data, the role of information technology is undeniable. Today, there is many dependencies between the firms' innovation performance, and it is evolving" (Thaker, Thaker, Khaliq, Pitchay, \& Hussain, 2019). Consequently, banks supervision moved their tactical philosophy of rivalry concerning "non-price and highquality services" by adopting a multi-channel information technology strategy (Salhieh, Abu-Doleh, \& Hijazi, 2011). Execution of information technologies for improvement of innovation performance indicates the firms' capacities to enhance and amend the current services and procedures to earn future benefits (Kramer, Marinelli, Lammarino, \& Diez, 2011). This study proposes the following research model (ref. Figure 1):

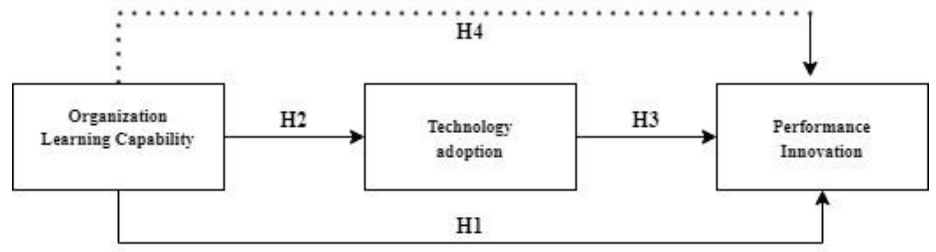

Figure 1: Research Framework

Research Methodology

This study prominence to measure the direct effects of organizational learning capability and technology adoption on performance. Innovation and the indirect effects of organizational learning capability on performance innovation with the mediating role of technology adoption. The study organized the quantitative approach by administering the questionnaire to collect the data for analyses. The banking industry of Pakistan was targeted for data collection using a simple random sampling technique. The items of the questionnaire were based on a 5-point Likert scale. One hundred fifty questionnaires were randomly disseminated; however, 134 filled questionnaires were acknowledged and analysed using Smart-PLS software. Table 1 exhibits the descriptive statistics of the respondents categorized into gender, age, and experience.

Table 1: Descriptive Statistics

\begin{tabular}{llcc}
\hline Controls & & \multicolumn{2}{c}{ Variance } \\
\hline \multirow{2}{*}{ Gender } & Male & 103 & $76.87 \%$ \\
& Female & 31 & $23.13 \%$ \\
Experience & 1-5 Years & 46 & $34.33 \%$ \\
& 6-10 Years & 42 & $31.34 \%$ \\
& 11-15 Years & 33 & $24.63 \%$ \\
& <15 Years & 13 & $10 \%$ \\
Age & 20-30 Years & 54 & $40.30 \%$ \\
& 31-40 Years & 41 & $30.60 \%$ \\
& 41-50 Years & 31 & $23.13 \%$ \\
& <50 Years & 7 & $5.22 \%$ \\
\hline
\end{tabular}

\section{Measures}

This paper applied the measures of constructs from the previous studies found in the literature. Organization learning capability was measured with three items adapted from the survey (Wang \& Kwek, 2018). Technology adoption was measured with five items taken from the study (Plewa, Troshani, Francis, \& Rampersad, 2012). In contrast, performance innovation was measured with three items adopted by the study (Wu, Mahajan, \& Balasubramanian, 2003).

\section{Results}

\section{Reliability and Validity}

Individual item reliability is recommended to be determined by the constructs (Duarte and Raposo, 2010; Hulland, 1999). Past studies have discussed a threshold that outer loadings should range from 0.40 to 0.70 (Hair et al., 2016). This study met the threshold of individual items loadings with 0.578 or higher values (ref. Table 2). Internal consistency reliability of composite reliability (CR) is suggested in past studies to be equal or above 0.7 (Bagozzi and Yi, 1988; Hair et al., 2011). CR for all the concepts in this study met the threshold with values of 0.911 and above (ref. Table 2). Past studies also suggest that Average Variance Extracted (AVE) or convergent validity should be used to determine the variables' convergent validity (Fornell and Larcker, 1981). The threshold for this in past studies is the value of 0.50 or above. The present study met the standard with the values of 0.643 and above (Chin, 1988) (ref. Table 2). The Cronbach alpha (CA) for this study is also within the standard range (0.70-0.90), as suggested by the previous studies. The Cronbach alpha of the study variables is 0.823 or above (ref. Table 2).

Table 2: Measurement Model

\begin{tabular}{|c|c|c|c|c|c|c|}
\hline \multirow{2}{*}{\multicolumn{4}{|c|}{$\begin{array}{ll}\text { Construct } & \text { Item code } \text { Loading P-value } \\
\text { Organizational learning capability (OLC) }\end{array}$}} & $\mathbf{C A}$ & $\mathbf{C R}$ & AVE \\
\hline & & & & 0.857 & 0.911 & 0.643 \\
\hline & OLC1 & 0.845 & $<0.000$ & & & \\
\hline & OLC2 & 0.752 & $<0.000$ & & & \\
\hline & OLC3 & 0.799 & $<0.000$ & & & \\
\hline \multicolumn{4}{|c|}{ Technology Adoption (TA) } & 0.921 & 0.923 & 0.633 \\
\hline & TA1 & 0.811 & $<0.000$ & 0.823 & 0.912 & 0.826 \\
\hline & TA2 & 0.822 & $<0.000$ & & & \\
\hline & TA3 & 0.756 & $<0.000$ & & & \\
\hline & TA4 & 0.768 & $<0.000$ & & & \\
\hline & TA5 & 0.913 & $<0.000$ & & & \\
\hline \multicolumn{4}{|c|}{ Performance Innovation (PI) } & 0.913 & 0.931 & 0.616 \\
\hline & PI1 & 0.578 & $<0.000$ & & & \\
\hline & PI2 & 0.811 & $<0.000$ & & & \\
\hline & PI3 & 0.873 & $<0.000$ & & & \\
\hline
\end{tabular}

\section{Assessment of Structural Model and Correlation}

In PLS-SEM, the VIF values address the collinearity issue of a structured model. Past studies discuss that (Hair et al., 2011; Kock, 2015), the VIF or standard method bias values should be lower or equal than 3.30, and this study has met the threshold (ref. Table 3). $\mathrm{R}^{2}$ is called the coefficient of determination of the variance in the dependent variable caused by the independent variables (Hair et al., 2016; Elliott and Woodward, 2007). Past studies revealed that in PLS-SEM, the value of $\mathrm{R}^{2}$ is standardized as 0.60 substantial, 0.33 moderate, and 0.19 weak (Chin, 1998). This study meets the rule of thumb with a significant effect of the predictor on turnover intention, as suggested by (Chin, 1998).

Moreover, $\mathrm{Q}^{2}$ refers to the Predictive Relevance Effect Sizes of the latent variables assessed through cross-validated redundancy (Ringle, Sarstedt, and Straub, 2012; Chin, 2010). This study met the threshold as discussed by the past studies that if the predictive relevance that exists in the model of the value of $\mathrm{Q}^{2}$ is higher than zero than it is measured as the presence of predictive relevance in the model (Henseler, Ringle and Sinkovics, 2009) (ref. Table 3). Furthermore, the present study met the threshold of the effect sizes 
of $\mathrm{F}^{2}$ (ref. Table 3). The study's findings exhibit the positive and significant relationships between the variables; for instance, organization learning capability and performance innovation have a positive relationship (0.478). Organization learning capability and technology adoption have positive relation (0.376), and technology adoption and performance innovation have significant association (0.791).

Table 3: Structured Model Results

\begin{tabular}{cccccc}
\hline Construct & $\begin{array}{c}\mathbf{Q} \\
\text { Square } \\
\left(\boldsymbol{Q}^{2}\right)\end{array}$ & $\begin{array}{c}\mathbf{R} \\
\text { Square } \\
(\boldsymbol{R} 2)\end{array}$ & $\begin{array}{c}\mathbf{R} \\
\text { Square } \\
\text { Adjusted }\end{array}$ & $\begin{array}{c}\text { Common } \\
\text { Method Bias } \\
(\boldsymbol{V I F})\end{array}$ & $\begin{array}{c}\boldsymbol{f} \\
\text { Square } \\
(\boldsymbol{F} 2)\end{array}$ \\
\hline $\mathrm{TI}$ & 0.30 & 0.654 & 0.653 & 1.15 & 0.132 \\
\hline
\end{tabular}

\section{Regression Analysis}

The present study used the PLS-SEM standard bootstrapping approach to examine the 134 observations of data and the constructed hypotheses (Hair et al., 2011). Findings show that hypothesis one (H1) has a significantly positive relationship among organizational learning capability and performance innovation $(\beta$ $=0.223, t=4.172, p<0.05$; ref. Table 4). Hypothesis two $(\mathrm{H} 2)$ also exhibits positive and significant effects of organizational learning capabilities on performance innovation $(\beta=0.364, t=6.213, p<0.05$; ref. Table 4). Moreover, hypothesis three (H3) showed a positive and significant effect of technology adaption on performance innovation $(\beta=0.710, t=16.463, p<0.05$; ref. Table 4). The current study evaluates the mediating role of technology adoption. This study used the approach recommended by Hair et al. (2016). As per Baron and Kenny (1986), the critical feature of indirect effect is that it consists of a third variable that acts as a mediating construct amongst the independent and dependents constructs. Furthermore, the impacts of independent construct $\mathrm{X}$ on the dependent construct $\mathrm{Y}$ are intermediated by a third construct $\mathrm{M}$, called the mediator. Preacher and Hayes (2008), explained this method as follows: "variable $\mathrm{M}$ is a mediator if $\mathrm{X}$ significantly account for variability in $\mathrm{M}, \mathrm{X}$ significantly accounts for variability in $\mathrm{Y}, \mathrm{M}$ significantly accounts for inconsistency in $\mathrm{Y}$ when controlling for $\mathrm{X}$, the effect of $\mathrm{X}$ on $\mathrm{Y}$ decrease considerably when $\mathrm{M}$ is entered concurrently with $\mathrm{X}$ as a predictor of $\mathrm{Y}$." The present study results show that direct effect from OLC to PI $(\beta=0.223, p=0.000)$, and TA to PI $(\beta=0.712$, $\mathrm{p}=0.000)$ were significant and positive statistically. As per Nitzl, Roldan, and Cepeda (2016), if the direct impact is not the significant and indirect outcome is significant, full mediation has happened; if equally direct and indirect effects are significant, partial mediation has happened (ref. Table 4). The indirect results showed that TA mediated between the relationship pf OLC and PI positively and significantly ( $\beta=0.258, t=4.168, p<0.05$; ref. Table 4).

Table 4: Hypothesis Constructs

\begin{tabular}{llccccc}
\hline & Relationships & Beta & SD & t-value & p-value & Decision \\
\hline H1 & OLC $\rightarrow$ PI & 0.223 & 0.056 & 4.172 & $0.000^{*}$ & Supported \\
H2 & OLC $\rightarrow$ TA & 0.364 & 0.054 & 6.213 & $0.000^{*}$ & Supported \\
H3 & TA $\rightarrow$ PI & 0.712 & 0.032 & 14.236 & $0.000^{*}$ & Supported \\
H4 & OLC $\rightarrow$ TA $\rightarrow$ PI & 0.258 & 0.033 & 4.168 & $0.000^{*}$ & Supported \\
\hline
\end{tabular}

\section{Conclusion and Discussion}

This study intended to determine the details of innovation performance affected by the organization's capability to learn and adopt the information technology for growth and success. The study projected that organizational learning capability affects information technology adoption and innovation performance positively and significantly. However, this study similarly clarifies that organizational learning capability has a positive and significant impact on innovation performance when the relationship is mediated by information technology adoption the same as the previous study of (Alegre \& Chiva, 2008). Previous research (Wu, Mahajan, \& Balasubramanian, 2003) explained that information technology adoption also positively and significantly impacts innovation performance. Hence it is concluded that in the banking industry of Pakistan under the current data analysis, the said variables have a significant effect. All of the hypotheses are approved by the analysis, validating that (also in mediation role). The banking industry assists the economy of every country being a significant part of monetary management. Therefore, banks always prefer to perform well for their own and state benefits. Hence, this study will help banks implement the results and achieve benefits from improving the product and services' performance and innovation. Also, the adoption of information technology will ease the customers for better management of activities. It will boost the usage of information to cope with new business management issues. In all these situations, organizational learning capability plays a significant role because it measures the level of information technology adoption and innovation performance. Future research can base different factors (variable) to inspect the effect on the banking industry's performance and provide better systems for adopting using and leaning information technology.

\section{References}

Alegre, J., and Chiva, R. (2008). Assessing the Impact of Organizational Learning Capability on Product Innovation Performance: An Empirical Test. Technovation, 28(06), 315-326. doi:10.1016/j.technovation.2007.09.003

Alwan, A., and Al-Zu'bi, I. A. (2016). Determinants of internet banking adoption among customers of commercial banks: An empirical study in the Jordanian banking sector. International Journal of Business and Management, 11(03), 95-104.

Ammirato, S., Sofo, F., Felicetti, M. A., and Raso, C. (2018). A methodology to support the adoption of IOT innovation and its application to the Italian bank branch security context. European Journal of Innovation Management, 22(01), 146-174. doi:https://doi.org/10.1108/EJIM-03-2018-0058

Bagozzi, R., and Yi, Y. (1988). On the evaluation of structural equation models. Journal of the Academy of Marketing Science, 16(01), 74-94.

Baron, R. M., and Kenny, D. A. (1986). The moderator-mediator variable distinction in social psychological research: Conceptual, strategic, and statistical considerations. Journal of Personality and Social Psychology, 51(6), 1173.

Bueno, E., and Ordonez, P. (2004). Innovation and learning in the knowledge-based economy: challenges for the firm International. Journal of Technology Management, 27(6/7), 515-524.

Chin, W. (2010). How to write up and report pls analyses. Handbook of partial least squares. Springer, 655-690.

Chin, W. W. (1988). The partial least squares approach to structural equation modeling. Modern Methods for Business Research, 295(02), 295-336.

Coccia, M. (2017). Sources of technological innovation: Radical and incremental innovation problem-driven to support competitive 
advantage of firms. Technology Analysis and Strategic Management, 29(09), 1048-1061. doi:10.1080/09537325.2016.1268682

Duarte, P. A., and Raposo, M. B. (2010). A PLS model to study brand preference: An application to the mobile phone market. Handbook of partial least squares. Springer, 449-485.

Elliott, A., and Woodward, W. (2007). Statistical analysis quick reference guidebook: With SPSS examples. Sage.

Ernst and Young. (2016). World Islamic Banking Competitiveness Report 2016. Retrieved from www. ey.com/Publication/vwLUAssets/ey-world-Islamic-bankingcompetitiveness-report-2016/ \$FILE/ey-world-islamic-bankingcompetitiveness-report-2016.pdf

Fornell, C., and Larcker, D. (1981). Evaluating structural equation models with unobservable variables and measurement error. Journal of Marketing Research, 18(01), 39-50.

Hair, J., Hult, G. M., Ringle, C., and Sarstedt, M. (2016). A primer on partial least squares structural equation modeling (PLS-SEM). Sage Publications.

Hair, J., Ringle, C., and Sarstedt, M. (2011). PLS-SEM: Indeed a silver bullet. Journal of Marketing Theory and Practice, 19(02), 139-152.

Hall, H. B., and Khan, B. (2003, May). Adoption of new technology. National Bureau of Economic Research. Retrieved from http://www.nber.org/papers/w9730

Hameed, M. A., Counsell, S., and Swift, S. (2012). A conceptual model for the process of IT innovation adoption in organizations. Journal of Engineering and Technology Management, 29(03), 358390.

Henseler, J., Ringle, C. M., and Sinkovics, R. (2009). The use of partial least squares path modeling in international marketing. New challenges to international marketing. Emerald Group Publishing Limited, 277-319.

Hulland, J. (1999). Use of partial least squares (PLS) in strategic management research: A review of four recent studies. Strategic Management Journal, 195-204.

Jenkins, H. (2007). Adopting internet banking services in a small Island State: Assurance of bank service quality. Managing Service Quality, 17(05), 523-537. Retrieved from http://dx.doi.org/10.1108/09604520710817343

Kock, N. (2015). Common method bias in PLS-SEM: A full collinearity assessment approach. International Journal of $e$ Collaboration (IJeC), 11(4), 1-10.

Kramer, J., Marinelli, E., Lammarino, S., and Diez, J. R. (2011). Intangible assets as drivers of innovation: empirical evidence on multinational eterprises in German and UK regional systems of innovation. Technovation, 31(19), 447-458. doi:10.1016/j.technovation.2011.06.005

Laput, G., Zhang, Y., and Harrison, C. (2017). Synthetic Sensors: Towards general-purpose Sensing . Proceedings of the 2017 CHI Conference on Human Factors in Computing Systems, 3986-3999.

Mandinach, E. B., and Cline, H. F. (2013). Implementing $a$ Technology-Based Learning Environment (1st ed.). Routledge.

Monostori, L. (2014). Cyber-physical production systems: Roots, expectations and randd challenges. Procedia CIRP, 17, 09-13. Retrieved

from www.sciencedirect.com/science/article/pii/S2212827114003497
Palacios-Marques, D., Devece-Cara' nana, C., and Llopis-Albert, C. (2016). Examining the effects of online social networks and organizational learning capability on innovation performance in the hotel industry. Psychology and Marketing, 33(12), 1126-1133. doi:10.1002/mar.20948

Plewa, C., Troshani, I., Francis, A., and Rampersad, G. (2012). Technology adoption and performance impact in innovation domains. Industrial Management and Data Systems, 112(05). doi: $10.1108 / 02635571211232316$

Preacher, K. J., and Hayes, A. F. (2008). Asymptotic and resampling strategies for assessing and comparing indirect effects in multiple mediator models. Behavior Research Method, 40(03), 879-891.

Rana, N., Weerakkody, V., Dwivedi, Y., and Piercy, N. (2014). Profiling existing research on social innovation in the public sector. Information Systems Management, 259-273.

Raza, A. M., Naveed, M., and Ali, S. (2017). Determinants of internet banking adoption by banks in Pakistan. Management and Organizational Studies, 04(04), 12-22. Retrieved from http s:// doi.org/10.5430/mos.v 4 n 4 p 12

Ringle, C. M., Sarstedt, M., and Straub, D. (2012). A critical look at the use of PLS-SEM in MIS quarterly. MIS Quarterly (MISQ), 36(01).

Salhieh, L., Abu-Doleh, J., and Hijazi, N. (2011). The assessment of e-banking readiness in Jordan. International Journal of Islamic and Middle Eastern Finance and Management, 04(04), 325-342. Retrieved from http://dx.doi.org/10.1108/17538391111186564

Siddik, N., Sun, G., Kabiraj, S., Shanmugan, J., and Yanjuan, C. (2016). Impacts of e-banking on performance of banks in a developing economy empirical evidence from Bangladesh. Journal of Business Economics and Management, 17(06), 1066-1088. doi:10.3846/16111699.2015.1068219

Spicer, D. P., and Sadler-Smith, E. (2006). Organizational learning in smaller manufacturing firms. International Small Business Journal, 24(02), 133-158. doi:10.1177/0266242606061836

Thaker, H., Thaker, M., Khaliq, A., Pitchay, A., and Hussain, H. (2019). Continuous adoption of internet banking: Evidence from Islamic banks in Malaysia. Manuscript to the 10th Foundation of Islamic Finance Conference "Advanced Research in Islamic Finance”. Sunway University, Malaysia.

The Demand Institute. (2017). The Demand Institute Report 2017. Retrieved from http://demandinstitute. org/

Valiris, G., and Glykas, M. (1999). Critical review of existing BPR methodologies: The need for a holistic approach. Business Process Management Journal, 05(01), 65-86.

Wang, Z., and Kwek, L. C. (2018). The mediation role of knowledge sharing between organizational learning and technological innovation practice. International Journal of Knowledge Management, 13(3), 48-68. doi:10.4018/IJKM.2018070104

Wu, F., Mahajan, V., and Balasubramanian, S. (2003). An analysis of e-business adoption and its impact on business performance. Journal of the Academy of Marketing Science, 31(04). doi:10.1177/0092070303255379

Yam, R. C., Lo, W., Tang, E. P., and Lau, A. K. (2011). Analysis of sources of innovation, technological innovation capabilities, and performance: An empirical study of Hong Kong manufacturing industries. Research Policy, 40(03), 391-402. doi:10.1016/j.respol.2010.10.013 